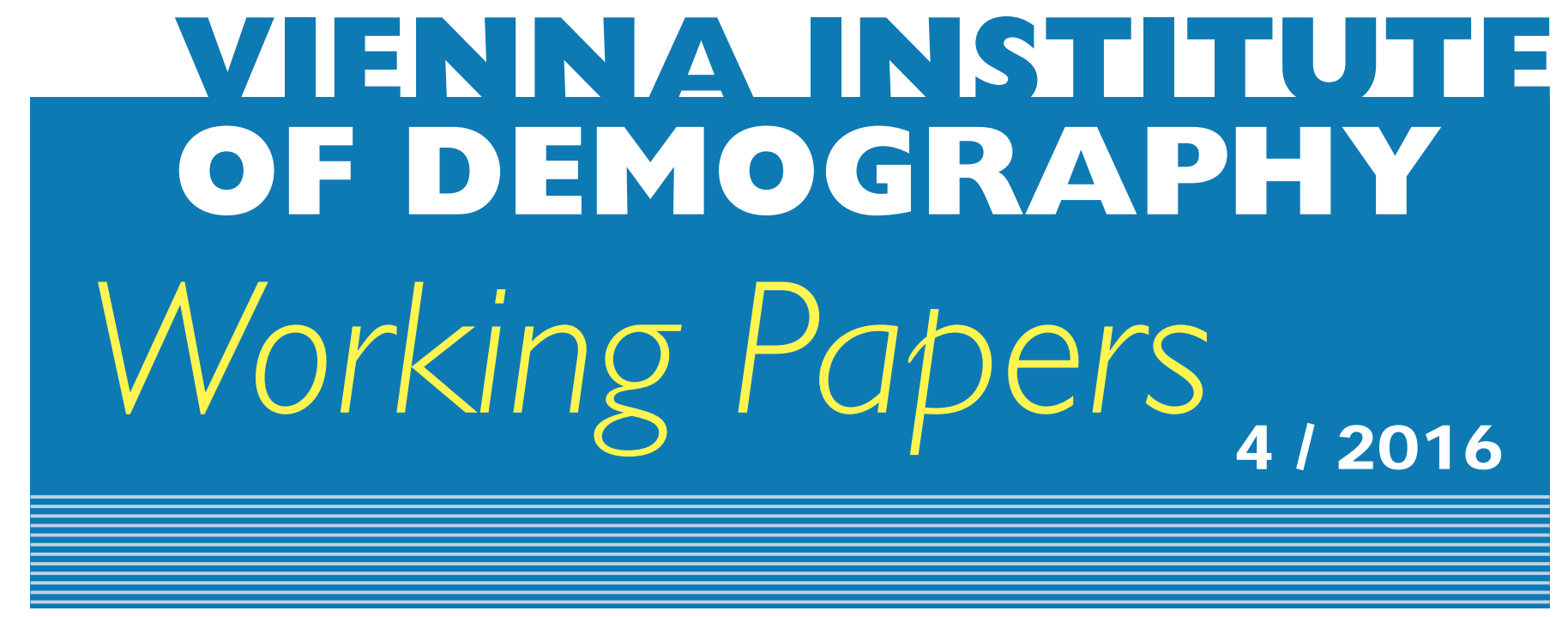

David E. Bloom, Michael Kuhn and Klaus Prettner

\title{
Africa's Prospects for Enjoying a Demographic Dividend
}

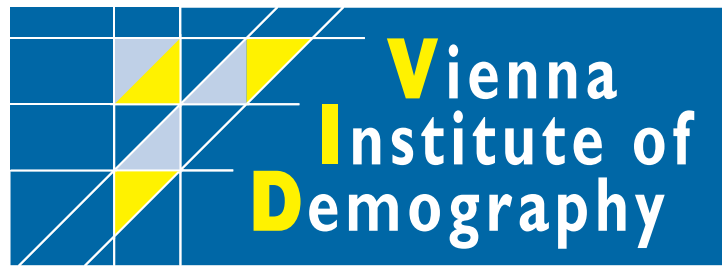

Vienna Institute of Demography Austrian Academy of Sciences

Welthandelsplatz 2 / Level 2

A-I020Vienna · Austria

E-Mail:vid@oeaw.ac.at

Website: www.oeaw.ac.at/vid 


\begin{abstract}
We assess Africa's prospects for enjoying a demographic dividend. While fertility rates and dependency ratios in Africa remain high, they have started to decline. According to United Nations projections, they will fall further in the coming decades such that by the mid- $21^{\text {st }}$ century the ratio of the working-age to dependent population will be greater than in Asia, Europe, and Northern America. This projection suggests Africa has considerable potential to enjoy a demographic dividend. Whether and when it actually materializes, and also its magnitude, hinges on policies and institutions in key realms that include macroeconomic management, human capital, trade, governance, and labour and capital markets. Given strong complementarities among these areas, coordinated policies will likely be most effective in generating the momentum needed to pull Africa's economies out of a development trap.
\end{abstract}

\title{
Keywords
}

Africa, declining fertility, demographic dividend, development, education, health, infrastructure.

\section{Authors}

David E. Bloom, Department of Global Health and Population, Harvard T.H. Chan School of Public Health, Boston MA, USA. Email: dbloom@hsph.harvard.edu

Michael Kuhn, Wittgenstein Centre (IIASA, VID, WU), Vienna Institute of Demography, Vienna, Austria. Email: michael.kuhn@oeaw.ac.at

Klaus Prettner, Institute of Economics, University of Hohenheim, Stuttgart, Germany. Email: klaus.prettner@uni-hohenheim.de 


\title{
Africa’s Prospects for Enjoying a Demographic Dividend
}

\author{
David E. Bloom, Michael Kuhn and Klaus Prettner
}

\section{Introduction}

According to the United Nations (2015), the total fertility rate (TFR) has been falling in developed regions from levels of 2.5-3.5 children per woman (Europe and Northern America in the 1960s) to levels far below the replacement rate of 2.1 children per woman in 2015. Africa started with a much higher TFR of 6.7 in the 1960s, which fell below the rate of 6 children per woman only in the 1990s. In 2015, the TFR in Africa was 4.7 children per woman, which is still far higher than in Europe and Northern America in the 1960s.

Figure 1: TFR and dependency ratio (population age $0-14$ and age 65+ divided by the population at age 15-64, x100) for Africa according to United Nations (2015)

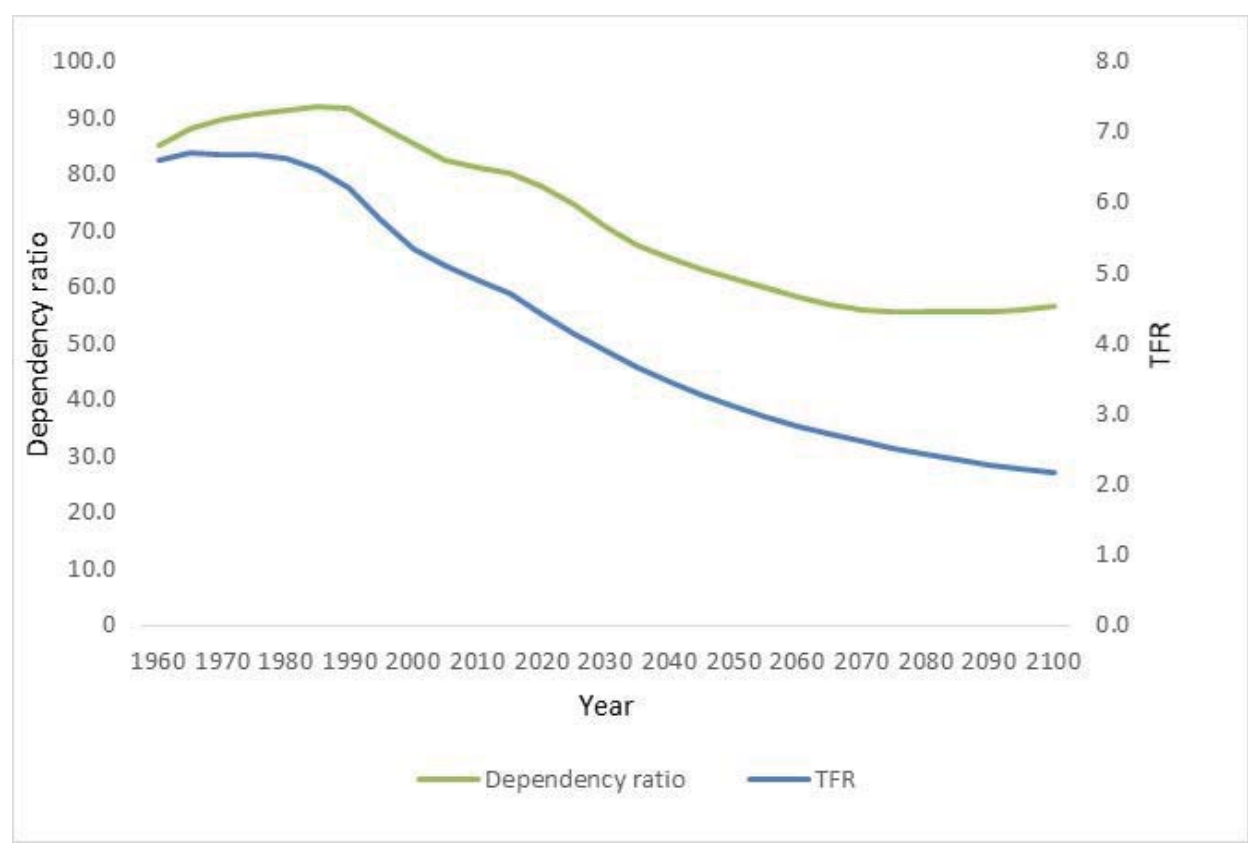

The transition from high to low fertility implies that the young dependent population declines in relation to the working-age population over time. Figure 1 plots Africa's TFR and dependency ratio according to United Nations (2015) current and projected data from 1960 to 
the end of the $21^{\text {st }}$ century. ${ }^{1}$ We observe that the fall in the dependency ratio is gradual and slower than the fall in fertility. The projections suggest that the dependency ratio will stabilize in the second half of the $21^{\text {st }}$ century, and only when the TFR stops falling and the smaller cohorts begin to retire will it start to increase again because of the rise of old-age dependency.

The decrease in the youth dependency ratio comes with various economic benefits, leading to what has been called the demographic dividend (Bloom et al., 2003). We can broadly decompose the demographic dividend into accounting effects and behavioural effects. The accounting effects capture the mechanical consequences of a declining population share of the young cohorts. Falling fertility gradually reduces the number of dependent young, while leaving the growth rate of the workforce unchanged until the smaller cohorts start to enter the workforce approximately one and a half to two decades later. As a consequence, the ratio of the workingage population to the dependent population increases, which tends to swell an economy's labour force, savings, and productive capacity on a per capita basis (Bloom and Freeman, 1988; Kelley and Schmidt, 2005). In later phases of the fertility transition, when the relatively smaller cohorts start to enter the workforce, capital dilution is mitigated and growth in the medium run increases by the standard mechanism of capital deepening that is well known from the Solow (1956) model. In less-developed countries where land remains an important input factor, a positive effect on per capita output also arises from the higher land-to-labour ratio that comes with declining fertility (Ashraf et al., 2013).

Changing individual choices under lower fertility drive the behavioural effects. We can distinguish among three main mechanisms. First, the decline in fertility tends to enable higher female labour force participation, which further raises the ratio of workers to the dependent population and thereby reinforces the corresponding accounting effect (Bloom et al., 2009). Second, declining fertility allows families and governments to invest more in the health and education of each child, i.e., a substitution of child quality for child quantity occurs along the lines of Becker and Lewis (1973). Better health and education of the young boost aggregate productivity growth once the young cohort enters the workforce. Third, because a large number of children often substitutes for old-age insurance in societies where social security systems are poorly developed (Boldrin et al. 2015), a decline in fertility implies that savings for retirement rise (either private savings or savings via a public pension system), which again reinforces capital deepening and thereby fosters growth in the medium run.

In Figure 2, we plot the dependency ratios for Africa, Asia, Europe, and Northern America according to United Nations (2015) current and projected data. We observe that the dependency ratio started to fall in Northern America and in Europe in the 1960s (after the baby boom) and in Asia in the late 1970s and the early 1980s, spurred by the one child policy in China. At the same time the dependency ratio was highest in Africa and even increased until the 1990s. It was still at a level of 80.1 in 2015, which was only slightly lower than Asia's 1965 dependency ratio of 80.3. United Nations (2015) projections for the next few decades imply that the dependency

\footnotetext{
${ }^{1}$ The dependency ratio is calculated as the ratio of the population at ages $0-14$ plus the population aged $65+$ to the population at ages 15-64.
} 
ratio will fall in Africa, while it has already started to rise in Europe and in Northern America because the baby-boom cohort has increased the number of retirees. By around 2040, Africa's dependency ratio will fall below the levels in Europe and in Northern America and stay lower throughout the rest of the $21^{\text {st }}$ century.

These projected changes imply that Africa has, a priori, large potential to enjoy a demographic dividend. Whether it actually does so depends crucially on the policies that the leaders of African countries implement. In this piece, we describe the main channels of and challenges to enjoying a demographic dividend, we quantify its potential economic growth effects, and we sketch possible ways for public policies to foster the emergence of a demographic dividend.

Figure 2: Dependency ratios (population age 0-14 and age 65+ divided by the population at age 15-64, x100) for different regions according to United Nations (2015)

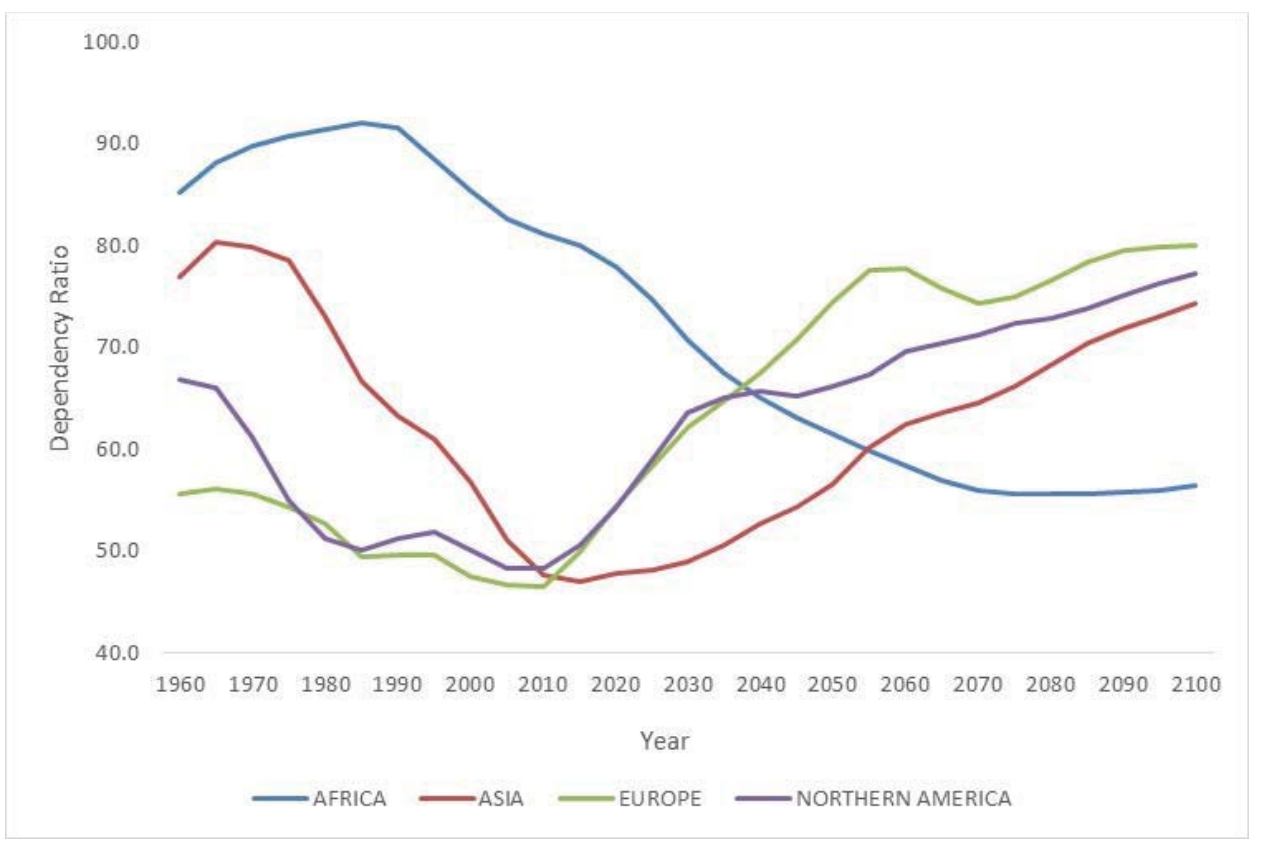

\section{Approaches to Analysing the Demographic Dividend and its Consequences}

The effects of declining fertility on economic growth are frequently assessed with simulated demographic-macroeconomic models along the lines of Lee and Mason (2010), Ashraf et al. (2013), and Mason et al. (2016). These frameworks calculate per capita output trajectories for various demographic scenarios, considering the effects on capital deepening, the propensity of parents to substitute child quality for quantity, and labour force participation. In particular, the 
models set forth in Ashraf et al. (2013) and Mason et al. (2016) allow us to trace the emergence over time of the "accounting" changes in the support ratio and the concomitant changes in physical and human capital investments.

Dynamic economic models that explain the economic stagnation before the industrial revolution and the ensuing rapid economic development (Galor and Weil, 2000; Galor, 2005, 2011) emphasize particularly the child quality-quantity substitution as the central mechanism behind a takeoff toward sustained long-run growth. An increase in education accompanies the decrease in fertility, leading to faster human capital accumulation and accelerated technological progress, and in turn driving growth of per capita GDP. Such unified growth models can also be applied to contemporaneous less-developed countries that are still in the midst of the transition to long-run economic growth (Bloom et al., 2015). Conceptually, these models provide a theoretical foundation for the mechanisms and incentives underlying investments in physical and human capital. Furthermore, most of these models derive their projected macroeconomic impacts from household-level analysis, allowing for an assessment of how social norms and government policies are fostering or hindering economic takeoff. These models address issues as varied as gender roles and female empowerment (e.g. Galor and Weil, 1996; de la Croix and Vander Donckt, 2010; Doepke and Tertilt, 2014; Prettner and Strulik, 2016a), social norms about contraception and prices of contraceptives (Prettner and Strulik, 2016b; Strulik, 2016), health improvements (e.g. Soares and Falcao, 2008; de la Croix and Vander Donckt, 2010; Bloom et al., 2015), and public infrastructure (Agenor et al., 2008; Agenor, 2010).

The empirical analysis of demographic effects on economic growth is typically based on cross-country convergence regressions of the type advanced by Barro (1991, 1997). Bloom and Williamson (1997, 1998) and Bloom et al. (2000) augment the framework to allow for a changing demographic structure. Their results also point to a favourable effect of a declining youth dependency ratio on economic development. ${ }^{2}$ Crespo Cuaresma et al. (2014) show that these effects materialize predominantly through an expansion of education.

\section{Implications for Economic Growth in Africa}

Using data from Nigeria, Ashraf et al. (2013) and Mason et al. (2016) study the impact of strong fertility decline relative to a scenario with moderate fertility decline. Ashraf et al. (2013) show in their baseline simulations that reducing fertility from the medium variant of the United Nations (2010) projections to the low variant, which corresponds to reducing the TFR by 0.5 children per woman, raises per capita GDP by 11.9 percent after 50 years. This corresponds to an increase in annual economic growth by 0.225 percentage points-a sizeable effect. Considering that the TFR of the African continent as a whole is projected to decrease from 5.71

\footnotetext{
${ }^{2}$ Thus far, the results are fully consistent with the empirical evidence on a negative correlation between economic growth and population growth (Brander and Dowrick, 1994; Kelley and Schmidt, 1995; Ahituv, 2001). Recent studies also address the issue of causality and find that, indeed, there is a causal negative effect of high fertility on economic growth (Li and Zhang, 2007; Herzer et al., 2012).
} 
in 2015 to 2.71 in 2065, these numbers imply that the economic growth rate would increase by 0.9 percentage points per year throughout this time span.

Building on the approach used in Ashraf et al. (2013), the volume edited by Canning et al. (2015) includes (in Chapter 4) a two-sector economic model, which suggests that reducing Nigeria's TFR from the high-variant level to a low-variant level would lead to a per capita income of over $\$ 13,000$ by 2060 (compared to $\$ 9,000$ in the high fertility scenario). The lower fertility variant also shows a larger and more rapid increase in the share of workers in manufacturing and a more rapid decline in agriculture. ${ }^{3}$ Regarding actionable steps towards fertility reduction, Bloom et al. (2014) show that fulfilling just one third of the unmet need for contraceptives in Kenya, Senegal, and Nigeria could lead to respective 16\%, 12\%, and 9\% increases in the countries' per capita incomes by $2030 .^{4}$

Bloom and Canning (2008) estimate that increasing the growth rate of the ratio of the working-age population to the total population by 1 percentage point leads, on average, to an increase in the per capita GDP growth rate of 1.394 percentage points. When applying the difference between the medium- and low-fertility variants in the Ashraf et al. (2013) simulations to the implied growth rate of the fraction of the working-age population, this implies that reducing the TFR by 0.5 would lead to an annual growth rate that is higher by 0.123 percentage points. For the projected TFR reduction of 2 children per woman in Africa, this would still imply a sizeable increase in the annual economic growth rate by 0.5 percentage points. The results for Asian countries in regressions by Bloom and Williamson (1998) and Bloom and Finlay (2009) and in growth accounting exercises by Mason (2001) are even larger. These studies find that approximately one third of East Asia's growth miracle — or 2 percentage points per year - can be explained by the favourable demographic shifts that followed a decline in fertility. Additionally, Bloom and Sachs (1998) estimate that the relatively youthful age structure of subSaharan Africa accounted for 19\% of the gap between the region's economic growth and that of the rest of the world from 1965 to $1990 .^{5}$

The simulations in Ashraf et al. (2013) and Mason et al. (2016) also allow us to identify the main drivers of the demographic dividend and how they evolve over the transition phase. Despite some differences in the modelling approach and in the variable of concern-per capita income in Ashraf et al. (2013) versus per capita consumption in Mason et al. (2016) - both papers find that while "accounting" changes in the support ratio initially drove the impact, investments in physical and human capital turned out to be the dominant drivers over the second part of the transition (broadly 50-100 years after the onset of fertility decline). ${ }^{6}$ Mason et al. (2016) show in addition that the increase in human capital rather than physical capital drives the

\footnotetext{
${ }^{3}$ Canning et al. (2015), page 158-160.

${ }^{4}$ Bloom et al. (2014), page 31.

${ }^{5}$ Bloom et al. (1998), page 261.

${ }^{6}$ More specifically, Mason et al. (2016) show that a shift in fertility from the moderate to the low UN scenario, starting in 2010 triggers a demographic dividend that initially amounts to about 0.6 percentage points and subsequently grows to 1 percentage point additional growth in per capita consumption in the period 2070-2100.
} 
demographic dividend once it becomes quantitatively important. ${ }^{7}$ UNFPA (2014) estimates that if countries in sub-Saharan Africa invest judiciously in human capital and combine it with effective labour market, capital market, and trade policies, and sound macroeconomic management and governance, they could collectively reap at least $\$ 500$ billion a year in economic benefits for up to 30 years, an economic boom akin to that experienced by East Asian countries during their period of rapid income growth.

\section{Crucial Channels and the Role of Complementarity}

The simulations by Ashraf et al. (2013) and Mason et al. (2016) show that a full demographic dividend in Africa will only materialize if a substantial increase in human capital investments accompanies - and in fact reinforces - the fertility decline. However, it is not clear this will happen: social norms and the complementarity among longevity, health investments, and education tend to induce a process that either boosts economic takeoff or stifles it, with the possible consequence of countries remaining in a development trap.

As multiple studies (cited earlier) show, social norms that are biased against gender equality tend to stifle female labour force participation, leading to low opportunity costs of children and thus to persistently high fertility. The same applies to social norms that militate against the use of contraception. With fertility remaining at high levels, the quality-quantity substitution cannot kick in, so investments in the human capital of children remain low. This observation points to the value of policies aimed at overcoming the social norms underlying persistently high fertility, including educational campaigns, facilitating female labour market access (even against a norm), and reducing labour market discrimination against women (Schober and Winter-Ebmer, 2011; Rees and Riezman, 2012). These policies may also involve less obvious measures, such as the creation or expansion of marketplaces which, based on Kenyan data, has been shown to dampen fertility by enhancing information exchange on modern methods of family planning (Kohler et al., 2001).

Complementarity hinders or boosts economic development through two channels: complementarity between health and education and complementarity between different forms of health investments (or behaviours) within a competing risk setting. With regard to the former, several studies document empirically that improvements that reduce (maternal) mortality and morbidity tend to boost (female) labour force participation and educational investments (e.g. Bleakley, 2007; Jayachandran and Lleras-Muney, 2009; Lucas, 2010; Albanesi and Olivetti, 2016), or as Bleakley (2011) points out, the productivity of education. Confirming the qualityquantity trade-off, Bleakley and Lange (2009) show that eradicating hookworm in the American south triggered a reduction in fertility. Significantly, health-education complementarity also translates across generations. Field et al. (2009) show for Tanzanian data how maternal iodine deficiency lowers cognitive ability and educational attainment, especially for daughters. Given

\footnotetext{
${ }^{7}$ For example, human capital investments explain about two thirds of the demographic dividend over the period 2040-2100 in Mason et al. (2106).
} 
that health deficiencies may thus hinder an education transition, the intergenerational persistence of poor health that has increased in Africa over the period 1970-2000 is of particular concern (Bhalotra and Rawlings, 2011).

The complementarity between general survival chances and specific health behaviours may lead to persistently poor health. As Oster (2012) shows for sub-Saharan Africa, individuals were more willing to reduce risky sexual behaviours in the face of HIV/AIDS when facing better general survival prospects (as measured by lower child mortality or lower incidence of malaria). This points to a clear risk of individuals doing little to prevent HIV due to low life expectancy overall, but at the same time it suggests that individuals may be investing little in general health due to the presence of HIV. Oster (2012) points out that this vicious cycle is naturally broken by policies that support health and healthy behaviour in general. ${ }^{8}$ Whether or not (persistently) high levels of HIV lead to a drag on growth is subject to some controversy: Young (2005) shows that, paradoxically, South Africa may benefit from HIV if shrinking the labour force triggers a wage increase, which stifles fertility by raising the opportunity cost of children. ${ }^{9}$ In contrast, Azomahou et al. (2016) confirm a growth drag induced by HIV, which is relatively stable in the early stages of an epidemic due to a direct loss of available labour (see also Cuddington and Hancock, 1994; Bloom et al., 2001), but then increases sharply due to the reduction in educational investments (see also Fortson, 2011). This closes the loop with our earlier considerations and illustrates that thoughtful policies have considerable potential to turn complementary incentives into a virtuous cycle of development.

\section{Policy Challenges}

A coherent political strategy is likely to maximize the chances of an economy's realizing a demographic dividend. Economic policies that foster fertility decline may be particularly effective. Direct policies may promote the use of contraceptives and family planning (Bhattacharya and Chakraborti, 2014; Prettner and Strulik, 2016b; Strulik, 2016). By providing maternal support and child health care, they may also seek to lower child mortality as a means of curbing precautionary fertility (Kalemli-Ozcan, 2003). Indirect policies aim at educating women, improving their health status, and facilitating female labour market access; these policies enhance female empowerment as an objective in its own right. But by improving the bargaining position of women, who typically prefer fewer and better educated children (Schultz, 1990; Thomas, 1990), and by raising the opportunity costs of children, they also contribute to lower fertility (Bloom et al., 2015; Prettner and Strulik, 2016a). At the same time, these policies may erode traditional social norms that are associated with high fertility. The crux is that escaping from development traps grounded in social norms and complementarities typically

\footnotetext{
${ }^{8}$ Dupas (2011) discusses other reasons for relatively low adoption of preventive health measures in developing countries. These include the presence of credit constraints or time-inconsistent preferences. Strikingly, information and education play an ambivalent role in fostering healthy behaviour (Cohen et al., 2015; Duflo et al., 2015).

${ }^{9}$ See also Young (2007). Studies by Fortson (2009), Kalemli-Ozcan (2012), and Juhn et al. (2013), however, do not support the view that overall fertility declines with the incidence of HIV.
} 
requires the coordination of policies across many areas (health, education, family planning). Furthermore, the most effective policies may be intensive early on and may only be relaxed once complementarities and social multipliers induce a takeoff. This raises issues as to whether local governments can cope with the coordination and front-loaded finance of such policies.

Once the youth dependency ratio decreases and unleashes resources for the government and for families to invest, the chances of enjoying a demographic dividend can then be further increased by resources being spent effectively on accumulating physical capital and human capital, particularly for the young population. Adequate policies, therefore, require combating corruption (Gyimah-Brempong, 2002; Bah and Fang, 2015) as well as building sound political, financial, and economic institutions (Ndulu and O’Connell, 1999; Block, 2002) and education and health care sectors with universal access. As the simulations by Ashraf et al. (2013) and Mason et al. (2016) show, such measures, if successful, would strongly reinforce an initial decline in fertility. At the same time, policy-makers would need to advance an environment with employment prospects for an increasingly well-educated population to avoid a brain drain to developed countries. Indeed, Hatton and Williamson (2003, 2011) report unmitigated emigration pressure from Africa. ${ }^{10}$ Open trade policies may have a role to play here; however, controversy remains as to whether (and what) forms of trade liberalization and promotion of foreign direct investment (FDI) may be conducive to development in general and whether or not Africa is different with regard to the trade/FDI-growth nexus (e.g. Collier and Gunning, 1999; Asiedu, 2001; Santos-Paulino and Thirlwall, 2004; Masanjala and Papageorgiou, 2008; Frazer and van Biesebroeck, 2010).

Possibly, the largest challenge to Africa enjoying a demographic dividend may come from climate change, which has been shown to have a strong direct impact on both output and output growth across all sectors (Dell et al. 2012) with further indirect effects through its detrimental impact on health and political stability (Dell et al. 2012, 2014). Collier et al. (2008) provide a survey of the consequences of climate change for Africa and possible policy responses, and Marchiori et al. (2012) provide evidence on the substantial impact of climate change on internal and external migration in sub-Saharan Africa. While these issues are beyond the scope of this survey, there are plausible indications that climate change and its consequences have the potential to undermine the conditions under which a demographic dividend may materialize for Africa.

A final challenge will arise if Africa actually enjoys a demographic dividend. Depending on how rapid the decline in fertility is, Africa would sooner or later face the challenge of an ageing population. ${ }^{11}$ This prospect, however, has been extensively dealt with elsewhere (e.g. Bloom et

\footnotetext{
${ }^{10}$ See also van Dalen et al. (2005) for a microeconomic analysis relating to the motivations to emigrate from Africa.

${ }^{11}$ According to the simulations in Mason et al. (2016), the support ratio does, indeed, deteriorate in the period from 2070-2100 for a radical decline in fertility from 6 births per women in 2010-15 to about 1.5 births in 2045 (mirroring the Chinese experience). However, the ongoing increase in human capital largely offsets the impact of this.
} 
al., 2003) and, at least for most parts of Africa, seems remote enough not to be included in this survey.

\section{Conclusions}

Overall, Africa's potential for enjoying a demographic dividend is large. Over the next few decades we expect the fertility rate to fall substantially, such that the dependency ratio decreases significantly. This will unleash resources to invest in education, infrastructure, health, and other productive areas. However, corruption and rent seeking by an extractive ruling elite could lead to a situation in which the gains from declining fertility are largely wasted and a demographic dividend does not emerge. In order to mitigate the effects of this possibility, African countries can establish inclusive institutions and follow growth-promoting economic policies to ensure that the window of opportunity presented by declining fertility can be used to raise welfare in the long run. Of course, the extent to which this is possible is likely to vary across countries according to their particular socio-economic, demographic, geographic, and cultural background.. 


\section{References}

Agenor, Pierre-Richard (2010) A theory of infrastructure-led development. Journal of Economic Dynamics and Control 34, 932-950.

Agenor, Pierre-Richard, Nihal Bayraktar, and Karim El Aynaoui, K (2008) Roads out of poverty? Assessing the link between aid, public investment, growth, and poverty. Journal of Development Economics 86, 277-295.

Ahituv, Avner (2001) Be fruitful or multiply: On the interplay between fertility and economic development. Journal of Population Economics 14, 51-71.

Albanesi, Stefania and Claudia Olivetti (2016) Gender roles and medical progress. Journal of Political Economy 124, 650-695.

Ashraf, Quamrul H., David N. Weil, and Joshua Wilde (2013) The effect of fertility reduction on economic growth. Population and Development Review 39, 97-130.

Asiedu, Elizabeth (2001) On the determinants of direct foreign investment to developing countries: Is Africa different? World Development 30, 107-119.

Azomahou, Théophile T, Raouf Boucekkine, and Bity Diene (2016) HIV/Aids and development: A reappraisal of the productivity and factor accumulation effects. American Economic Review, Papers \& Proceedings 106, 472-477.

Bah, El-hadj, and Lei Fang (2015) Impact of the business environment on output and productivity in Africa. Journal of Development Economics 114, 159-171.

Barro, Robert J. (1991) Economic growth in a cross section of countries. Quarterly Journal of Economics 106, 407-444.

Barro, Robert J. (1997) Determinants of economic growth: A cross-country empirical study. Cambridge, MA: MIT Press.

Becker, Gary S. and H, Gregg Lewis (1973) On the interaction between the quantity and quality of children. Journal of Political Economy 81, 279-288.

Bhalotra, Sonia and Samantha B. Rawlings (2011) Intergenerational persistence in health in developing countries: The penalty of gender inequality? Journal of Public Economics 95, 286-299.

Bhattacharya, Joydeep and Shankha Chakraborty (2014) Contraception and the fertility transition. MPRA Paper 53129, University Library of Munich, Germany.

Bleakley, Hoyt (2007) Disease and development: Evidence from hookworm eradication in the American south. Quarterly Journal of Economics 122, 73-117.

Bleakley, Hoyt (2011) Health, human capital, and development. Annual Review of Economics 2, 280-310.

Bleakley, Hoyt and Fabian Lange (2009) Chronic disease burden and the interaction of education, fertility, and growth. Review of Economics and Statistics 91, 52-65.

Block, Steven A. (2002) Political business cycles, democratization, and economic reform: The case of Africa. Journal of Development Economics 67, 205-228.

Bloom, David E. and David Canning (2008) Global demographic change: Dimensions and economic significance. Population and Development Review 34, 17-51. 
Bloom, David E. and David Canning, Günther Fink, and Jocelyn Finlay (2009) Fertility, female labor force participation, and the demographic dividend. Journal of Economic Growth 14, 79-101.

Bloom, David E. and David Canning, and Pia N. Malaney (2000) Population dynamics and economic growth in Asia. In: Chu, C. Y. C., and Lee. R. (Eds.). Population and economic change in East Asia. Population and Development Review 26, 257-290.

Bloom, David E. and David Canning, and JP Sevilla (2003) The demographic dividend. Population matters. A RAND Program of Policy-Relevant Research Communication, Santa Monica, California.

Bloom, David E. and Richard B. Freeman (1988) Economic Development and the Timing and Components of Population Growth. Journal of Policy Modeling, April, 57-82.

Bloom, David E. and Jocelyn Finlay (2009) Demographic change and economic growth in Asia. Asian Economic Policy Review 4, 45-64.

Bloom, David E., Kuhn, M., and Prettner, K. (2015) The contribution of female health to economic development. NBER Working Paper No. 21411, National Bureau of Economic Research, Cambridge, Massachusetts.

Bloom, David E., Salal Humair, Larry Rosenberg, JP Sevilla and James Trussell (2014) Capturing the demographic dividend: Source, magnitude and realization. In: Soucat, A. and Ncube, M. (Eds.). One billion people, one billion opportunities: Building human capital in Africa. Addis Ababa: African Development Bank, 23-41.

Bloom, David E., Ajay Mahal, A., JP Sevilla, and River Path Associates. (2001). AIDS and economics. Paper prepared for Working Group 1 of the WHO Commission on Macroeconomics and Health, Geneva, Switzerland.

Bloom, David E. and Jeffrey D. Sachs (1998). Geography, Demography, and Economic Growth in Africa. Brookings Papers on Economic Activity 29 (2), 207-295.

Bloom, David E. and Jeffrey G. Williamson (1997) Demographic change and human resource development. In: Emerging Asia: Changes and challenges. Manila: Asian Development Bank, 141-197.

Bloom, David E. and Jeffrey G. Williamson (1998) Demographic transitions and economic miracles in emerging Asia. World Bank Economic Review 12, 419-456.

Boldrin, Michele, Mariacristina De Nardi and Larry E. Jones (2015) Fertility and social security. Journal of Demographic Economics 81, 261-299.

Brander, James A. and Steve Dowrick, (1994) The role of fertility and population in economic growth. Journal of Population Economics 7, 1-25.

Canning, D., Sangeeta Raja, and Abdo S. Yazbeck (Eds.) (2015) Africa's Demographic Transition: Dividend or Disaster? Washington, DC: World Bank Group.

Cohen, Jessica, Pascaline Dupas, and Simone Schaner (2015) Price subsidies, diagnostic tests, and targeting of malaria treatment: Evidence from a randomized controlled trial. American Economic Review 105, 609-645.

Collier, Paul, Gordon Conway, and Tony Venables (2008) Climate change and Africa. Oxford Review of Economic Policy 24, 337-353.

Collier, Paul, and Jan W. Gunning (1999) Explaining African economic performance. Journal of Economic Literature 37, 64-111. 
Crespo Cuaresma, Jesus, Wolfgang Lutz, and Warren Sanderson (2014) Is the demographic dividend an education dividend? Demography 51, 299-315.

Cuddington, John T. and John D. Hancock (1994) Assessing the impact of AIDS on the growth of the Malawian economy. Journal of Development Economics 77, 107-124.

de la Croix, David and Marie Vander Donckt (2010) Would empowering women initiate the demographic transition in least developed countries? Journal of Human Capital 4, 85-129.

Dell, Melissa, Benjamin F. Jones and Benjamin A. Olken (2012) Temperature shocks and economic growth: evidence from the last half century. American Economic Journal: Macro 4, 66-95.

Dell, Melissa, Benjamin F. Jones and Benjamin A. Olken (2014) What do we learn from the weather? The new climate-economy literature. Journal of Economic Literature 52, 740-798.

Doepke, Matthias and Michèle Tertilt (2014) Does female empowerment promote economic development? NBER Working Paper 1988, National Bureau of Economic Research, Cambridge, Massachusetts.

Duflo, Esther, Pascaline Dupas, and Michael Kremer (2015) Education, HIV, and early fertility: Experimental evidence from Kenya. American Economic Review 105, 2759-2797.

Dupas, Pascaline (2011) Health behaviors in developing countries. Annual Review of Economics, 3, 425-449.

Field, Erica, Omar Robles, and Maximo Torero (2009) Iodine deficiency and schooling attainment in Tanzania. American Economic Journal: Applied Economics, 1, 140-169.

Fortson, Jane G (2009) HIV/AIDS and fertility. American Economic Journal: Applied Economics 1, 170-194.

Fortson, Jane G. (2011) Mortality risk and human capital investment: The impact of HIV/AIDS in sub-Saharan Africa. Review of Economics and Statistics 93, 1-15.

Frazer, Garth and Johannes van Biesebroeck (2010). Trade growth under the African Growth and Opportunity Act. Review of Economics and Statistics 92, 128-144.

Galor, Oded (2005). From stagnation to growth: Unified growth theory. In: Handbook of Economic Growth, Noth Holland, Elsevier, 171-293.

Galor, Oded (2011). Unified growth theory. Princeton University Press.

Galor, Oded and David Weil (1996) The gender gap, fertility, and growth. American Economic Review 86, 374-387.

Galor, Oded and David Weil (2000) Population, technology, and growth: From Malthusian stagnation to the demographic transition and beyond. The American Economic Review 90, 806-828.

Gyimah-Brempong, Kwabena (2002) Corruption, economic growth, and income inequality in Africa. Economics of Governance 3, 183-209.

Hatton, Timothy J. and Jeffrey G. Williamson (2003) Demographic and economic pressure on emigration out of Africa. The Scandinavian Journal of Economics 105, 465-486.

Hatton, Timothy J. and Jeffrey G. Williamson (2011) Are third world emigration forces abating? World Development 39, 20-32.

Herzer, Dierk, Holger Strulik, and Sebastian Vollmer (2012) The long-run determinants of fertility: One century of demographic change 1900-1999. Journal of Economic Growth 17, 357-385. 
Jayachandran, Seema and Adriana Lleras-Muney (2009) Life Expectancy and Human Capital Investments: Evidence from Maternal Mortality Declines, The Quarterly Journal of Economics 124, 349-397.

Juhn, Chinhui, Sebnem Kalemli-Ozcan, and Belgi Turan (2013) HIV and fertility in Africa: First evidence from population-based surveys. Journal of Population Economics 26, 835-853.

Kalemli-Ozcan, Sebnem (2003) A stochastic model of mortality, fertility, and human capital investment. Journal of Development Economics 70, 103-118.

Kalemli-Ozcan, Sebnem (2012) AIDS, "reversal" of the demographic transition and economic development: Evidence from Africa. Journal of Population Economics 25, 871-897.

Kelley, Allen C. and Robert M. Schmidt (1995) Aggregate population and economic growth correlations: The role of the components of demographic change. Demography 32, 543-555.

Kelley, Allen C. and Robert M. Schmidt (2005) Evolution of recent economic-demographic modeling: A synthesis. Journal of Population Economics 18, 275-300.

Kohler, Hans-Peter, Jere R. Behrman, and Susan C. Watkins (2001) The density of social networks and fertility decisions: Evidence from the South Nyanza District, Kenya. Demography 38, 43-58.

Lee, Ronald, and Andrew Mason (2010) Fertility, human capital, and economic growth over the demographic transition. European Journal of Population 26, 159-182.

Li, Hongbin and Junsen Zhang (2007) Do high birth rates hamper economic growth? Review of Economics and Statistics 89, 110-117.

Lucas, Adrienne M. (2010) Malaria eradication and educational attainment: Evidence from Paraguay and Sri Lanka. American Economic Journal: Applied Economics 2, 46-71.

Masanjala, Winford H. and Chris Papageorgiou (2008) Rough and lonely road to prosperity: A reexamination of the sources of growth in Africa using Bayesian model averaging. Journal of Applied Econometrics 23, 671-682.

Marchiori, Luca, Jean-François Maystadt, and Ingmar Schumacher (2012) The impact of weather anomalies on migration in sub-Saharan Africa. Journal of Environmental Economics and Management 63, 355-374.

Mason, Andrew, ed. (2001) Population change and economic development in East Asia: Challenges met, opportunities seized. Stanford University Press.

Mason, Andrew, Ronald Lee, and Jennifer Xue Jiang (2016) Demographic dividends, human capital, and saving. The Journal of the Economics of Ageing 7, 106-122.

Ndulu, Benno J., and Stephen A. O’Connell (1999) Governance and growth in sub-Saharan Africa. Journal of Economic Perspectives 13, 41-66.

Oster, Emily (2012) HIV and sexual behavior change: Why not Africa? Journal of Health Economics 31, 35-49.

Prettner, Klaus and Holger Strulik (2016a) Gender equity and the escape from poverty. Oxford Economic Papers (forthcoming).

Prettner, Klaus and Holger Strulik (2016b) It's a sin-Contraceptive use, religious beliefs, and long-run economic development. Review of Development Economics (forthcoming).

Rees, Ray and Ray Riezman (2012) Globalization, gender, and growth. Review of Income and Wealth 58, 107-117. 
Santos-Paulino, Amelia U. and A. P. Thirlwall (2004) The impact of trade liberalization on exports, imports, and the balance of payments of developing countries. Economic Journal 114, F50-F72.

Schober, Thomas and Rudolf Winter-Ebmer (2011) Gender wage inequality and economic growth: Is there really a puzzle?-A comment. World Development 39, 1476-1484.

Schultz, T. Paul (1990) Testing the neoclassical model of family labour supply and fertility. Journal of Human Resources 25, 599-634.

Soares, Rodrigo R. and Bruno L. S. Falcao (2008) The demographic transition and the sexual division of labor. Journal of Political Economy 116, 1058-1104.

Solow, Robert M (1956) A contribution to the theory of economic growth. The Quarterly Journal of Economics 70, 65-94.

Strulik, Holger (2016) Contraception and development: A unified growth theory. International Economic Review (forthcoming).

Thomas, Duncan (1990) Intra-household resource allocation: an inferential approach. Journal of Human Resources 25, 635-664.

United Nations (2010) World population prospects: The 2010 revision. Department of Economic and Social Affairs, Population Division, New York.

United Nations (2015) World population prospects: The 2015 revision. Department of Economic and Social Affairs, Population Division, New York.

UNFPA (2014) State of the World Population 2014. United Nations Population Fund, New York.

van Dalen, Hendrik P., George Groenewold, and Jeannette J. Schoorl (2005) Out of Africa: What drives the pressure to emigrate? Journal of Population Economics 18, 741-778.

Young, Alwyn (2005) The gift of the dying: The tragedy of AIDS and the welfare of future African generations. Quarterly Journal of Economics 120, 423-466.

Young, Alwyn (2007) In sorrow to bring forth children: Fertility amidst the plague of HIV. Journal of Economic Growth 12, 283-327. 


\section{VIENNA INSTITUTE OF DEMOGRAPHY Working Papers}

Frankovic, Ivan, Michael Kuhn and Stefan Wrzaczek, Medical Care within an OLG Economy with Realistic Demography, VID Working Paper 3/2016.

Abel, Guy J., Estimates of Global Bilateral Migration Flows by Gender between 1960 and 2015, VID Working Paper 2/2016.

Testa, Maria Rita, Valeria Bordone, Beata Osiewalska and Vegard Skirbekk, The Relation between Mother's Socio-Economic Status and Daughter's Fertility Intentions in Austria, Italy, Bulgaria, and Norway, VID Working Paper 1/2016.

Hoffmann, Roman and Raya Muttarak, A Tale of Disaster Experience in Two Countries: Does Education Promote Disaster Preparedness in the Philippines and Thailand, VID Working Paper 9/2015.

Klotz, Johannes and Richard Gisser, Mortality Differentials by Religious Denomination in Vienna 1981-2002, VID Working Paper 8/2015.

Steiber, Nadia and Barbara Haas, Overworked or Underemployed? Actual and Preferred Household Employment Patterns in the Context of the Economic Crisis, VID Working Paper 7/2015.

Beaujouan, Eva, Zuzanna Brzozowska and Krystof Zeman, Childlessness Trends in Twentieth-Century Europe: Limited Link to Growing Educational Attainment, VID Working Paper 6/2015.

Abel, Guy, Estimates of Global Bilateral Migration Flows by Gender between 1960 and 2010, VID Working Paper 5/2015.

Spijker, Jeroen, Alternative Indicators of Population Ageing: An Inventory, VID Working Paper 4/2015.

Kuhn, Michael and Klaus Prettner, Population Structure and Consumption Growth: Evidence from National Transfer Accounts, VID Working Paper 3/2015.

Sobotka, Tomáš, Low Fertility in Austria and the Czech Republic: Gradual Policy Adjustments, VID Working Paper 2/2015.

Buber-Ennser, Isabella, Aspects of Gender Mainstreaming of Family and Work in Austria, VID Working Paper 1/2015.

The Vienna Institute of Demography Working Paper Series receives only limited review. Views or opinions expressed herein are entirely those of the authors. 